Fjeld, Hagen, Henriksen, Johansson, Olsen \& Prentice (eds.) Academic Language in a Nordic

OSLa Setting - Linguistic and Educational Perspectives, Oslo Studies in Language 9(3), 2017. 29-44.

(ISSN 1890-9639)

http://www. journals.uio.no/osla

\title{
ACADEMIC VOCABULARY IN TEACHER TALK: CHALLENGES AND OPPORTUNITIES FOR PEDAGOGY
}

\author{
AVERIL COXHEAD
}

\section{ABSTRAC T}

This article focuses on the opportunities and challenges afforded by teacher talk in Grade Six (10 and 11 year old students) English as an Additional Language, Maths, and Science classes in an international school context in Germany. Teachers recorded their classroom discourse for one week of classes three times in one academic year in each subject. The data shows that high frequency vocabulary prevails in all three subject areas, and Science has a higher vocabulary load than the other two subjects overall. The amount of academic vocabulary, measured by Coxhead's (2000) Academic Word List, and science vocabulary, measured by Coxhead \& Hirsh's EAP Science List (2007), were lower over the teacher talk than over secondary school textbooks. This means that teacher talk is lexically easier than textbooks. Over the course of the year, the vocabulary load of the teacher talk increases in all three subjects. This article looks at opportunities and challenges presented by the lexis of teacher talk in these subjects for second and foreign language students in these classes and their teachers. Suggestions for further research are presented by way of a conclusion.

\section{[1] INTRODUCTION}

In an international school context, learners are expected to be able to cope with the English language, the subject content and the educational context at the same time. For some students this will be a relatively easy task, for others it will be a significant challenge. A class of Grade Six students in their first year of high school in an international school in Germany may well contain native speakers of English as well as non-native speakers. Any of these students might well have been educated in several countries that may or may not be part of Anglo-European schooling over their lifetimes and speak one or several languages at home. Their teachers could be non-native or native speakers of English.

A key element in classroom learning contexts is the vocabulary needed to 
understand written texts, including textbooks, as well as the spoken texts of the classroom, such as teacher talk. These written and spoken sources of input are vital elements of education for content and language learning. Studies into vocabulary in secondary school contexts tend to have focused on written texts, through corpus-based studies of textbooks such as Greene \& Coxhead's (2015) study of Middle School vocabulary in textbooks in the USA and Coxhead, Stevens \& Tinkle's (2010) analysis of a series of Science textbooks in Aotearoa/New Zealand. Very few studies have focused on the vocabulary of teacher talk. Gibbons (2006: 1) draws attention to the importance of talk in language learning contexts when she writes,

... [t]he talk of teachers and students draws together - or bridges - the 'everyday' language of students learning through English as a second language, and the language associated with the academic registers of school which they must learn to control.

If learners in a secondary school classroom have a large vocabulary in English, then dealing with the vocabulary load of teacher talk is presumably less problematic than for those with a smaller vocabulary.

Unfortunately, studies have shown low vocabulary scores for high school learners of English as a foreign language in a range of countries, including Indonesia (Nurweni \& Read, 1999), Denmark (Henriksen \& Danelund, 2015), Taiwan (Webb \& Chang, 2012), and Spain (Olmos, 2009). The Danish, Taiwanese and Spanish studies used the Vocabulary Levels Test (VLT) (Nation, 1983; Schmitt, Schmitt \& Clapham, 2001). The VLT is a receptive, frequency-based test with five sections: high frequency vocabulary in the first 2000 and 3000 words, through to lower frequency levels at 5000, and 10000. There is an academic section, based on Coxhead's Academic Word List (AWL). Out of the 30 items at each level of the test, test takers need to score 26 to indicate mastery of that level. In the international school in Germany reported on in this study, over 100 nonnative speaking Grade 6 students scored below mastery of the first 2000 words of English (under review). These results suggest that the students would not be able to cope with the vocabulary load of the textbooks which were written for first language readers. It is important to investigate teacher talk to find out whether this form of input is a bridge between everyday English and lexically difficult textbooks.

\section{[1.1] Teacher talk and vocabulary}

Several studies which have focused on teacher talk have concluded that it is lexically poor (Horst, 2010; Tang, 2011). Horst (2010) used a corpus of 121,000 
running words of teacher talk from English as Second Language (ESL) community conversation classes over the course of nine weeks in Canada. She found that $98 \%$ of the vocabulary in the teacher talk was from the first 4,000 words of English, and concludes that incidental acquisition of vocabulary was not very efficient, needing supplementary work by teachers and study by learners (page 177). Extrapolating the results of three scripts of 9,500 words and categorising the focus of the teacher talk, she found 53\% focused on classroom management and activity; $41 \%$ on language; and 5\% on texts (Horst, 2010: 167). Tang (2011) recorded one week of teaching of six non-native speaker teachers in several Chinese universities and found that approximately $79 \%$ of the talk was covered by the first 2,000 word families of Nation's British National Corpus (BNC) (2006) lists, and that words outside those lists mostly came from textbooks. Horst (2010) and Tang (2011) conclude that teacher talk had little to offer in the way of vocabulary for learning for students.

Gierlinger \& Wagner (2016) undertook a study of vocabulary knowledge in a lower secondary school in Austria which used a CLIL approach. As part of their study, they recorded 10 hours of teacher talk (four hours in Chemistry and History and two hours in Geography), which gleaned around 19,000 running words of text. Gierlinger \& Wagner's (2016) analysis of this small corpus uncovered a predominance of high frequency vocabulary across all three subjects.

Watanabe's (2013) study of teacher talk of two speakers of British English teaching three classes (one taught two classes and the other taught one class) in an English for Academic Purposes (EAP) programme in Japan illustrated that the vocabulary of a teacher's classroom language may differ a great deal depending on the subject of the class. Watanabe (2013) noted differences in the high frequency vocabulary used by the teachers as well as their academic vocabulary use, based on Coxhead's Academic Word List (AWL). The percentage of AWL items in the teacher talk differed between the type of class (study skills vs content-based) and between teachers $(2.39 \%$ and $4.53 \%$ by one teacher from two different classes and $9.77 \%$ by the other). Teacher talk in an adult EAP class could be quite different from a secondary school classroom context, but little research has investigated this point.

\section{[1.2] Vocabulary load analyses}

Vocabulary load research focuses on the number of word families needed to reach particular levels of coverage of texts. Nation (2006) reports on coverage figures for newspapers, novels, and university-level texts using his British National Corpus word lists: 8,000-9,000 word families plus proper nouns are needed for coverage of up to $98 \%$. Coxhead, Stevens \& Tinkle (2010) reported similar 
coverage of a series of Science textbooks from secondary school in Aotearoa/New Zealand. The vocabulary load was higher for senior level text books. But research on listening comprehension by van Zeeland \& Schmitt (2013) suggests that for general spoken English texts, comprehension by non-native speakers was 'relatively good' at $95 \%$. This figure suggests that the vocabulary load of spoken texts is lower than for written texts, at 2,000-3,000 word families. In a classroom setting, with support for learning, the $95 \%$ coverage figure may well be enough to report on the vocabulary load of teacher talk from English as an Additional Language, Maths, and Science classrooms.

\section{[1.3] Academic and Science word lists}

The Academic Word List (Coxhead, 2000) has been used as a measure for a range of academic texts (see Coxhead, 2000; 2011). The list contains 570 word families and was developed using a written academic corpus of 3.5 million words. The corpus contained four disciplines, each containing seven subject areas. The coverage of the AWL over written academic texts in Coxhead's study was $10 \%$, and many studies since have reported coverage figures over different written academic corpora from $7 \%$ through to $11 \%$ (Coxhead, 2011). Dang \& Webb (2014) estimate that the AWL covers up to $4 \%$ university spoken texts.

Building on the AWL, Coxhead \& Hirsh (2007) developed an EAP Science List. This list contains 318 word families and its coverage of a first year university written academic science corpus was $3.79 \%$. Coxhead, Stevens \& Tinkle (2010) found $5.9 \%$ coverage by the EAP Science List over their secondary Science textbook series. This finding suggests that the list is potentially more useful for secondary school science students than for university level students. To the best of my knowledge, no research has used this list to investigate the use of Science vocabulary in teacher talk in secondary school in English.

Nation \& Webb (2011, p. 238) note the value of learning more about vocabulary learning through listening. This study looks at the affordances for learning vocabulary through one source of listening in schools: teacher talk.

\section{[1.4] Research questions}

This study has three research questions:

1. What is the vocabulary load of the teacher talk in the EAL, Maths and Science classes in this study?

2. Do the vocabulary load figures change over the course of a school year?

3. What coverage do the AWL and EAP Science word lists have over the teacher talk corpora? 


\section{[2] METHODOLOGY}

Three teachers took part in this study: a female Maths teacher from North America; a male Science teacher from Germany; and a female EAL teacher who claims dual origins from Australia and Aotearoa/New Zealand. These teachers were volunteers for this project and their subjects are all part of the Grade Six school curriculum. The teachers wore recording devices and were free to turn them on and off whenever they liked during a lesson. That said, teachers kept the recordings going for each class. For each week of the recordings, the teachers recorded a full week of classes with the Grade Six students (i.e., 5 x $40 \mathrm{mi}$ nute period). The recordings took place at the start of the school year in September 2014; in late January/early February 2015; and in July 2015. These times of the year were selected to provide a way to compare and contrast the teacher talk over the course of the year in the different subjects, to limit disruption to classes, and to ensure that teachers' goodwill towards the project remained intact as much as possible.

Table 1 shows the teacher talk data set (107,587 words). Maths has the greatest number of running words at almost 47,000 and EAL has the least at nearly 30,000 . The amount of text is roughly equal for each time, with the lowest amount at 32,920 for the first set of recordings in September 2014 and the most in the second set of recordings, due to the large amount of teacher talk in Maths for that week.

\begin{tabular}{ccccc}
\hline & $\begin{array}{c}\text { Time 1 } \\
\text { (Sept 2014) }\end{array}$ & $\begin{array}{c}\text { Time 2 } \\
\text { (Jan/Feb2015) }\end{array}$ & $\begin{array}{c}\text { Time 3 } \\
\text { (Jun/Jul2015) }\end{array}$ & Total \\
\hline Maths & 14,653 & 19,744 & 12,540 & 46,937 \\
EAL & 8,875 & 8,117 & 12,442 & 29,434 \\
Sciences & 9,392 & 11,623 & 10,201 & 31,216 \\
$\begin{array}{c}\text { All three sub- } \\
\text { jects }\end{array}$ & 32,920 & 39,484 & 35,183 & 107,587 \\
\hline
\end{tabular}

TABLE 1: Word counts for each week and each subject in the teacher talk corpus

Vocabulary is motivated by the topic under discussion. Table 2 contains a list of the topics in the lessons. Each lesson was transcribed and the transcripts were checked for accuracy. 


\begin{tabular}{|c|c|c|c|}
\hline & EAL & Maths & Sciences \\
\hline $\begin{array}{l}\text { Start of the } \\
\text { year (Septem- } \\
\text { ber 2014) }\end{array}$ & $\begin{array}{l}\text { Administration } \\
\text { Vocabulary test } \\
\text { Vocabulary strate- } \\
\text { gies and admin- } \\
\text { istration }\end{array}$ & $\begin{array}{l}\text { Long division } \\
\text { Estimation and ap- } \\
\text { proximation } \\
\text { Long division with } \\
\text { remainders }\end{array}$ & $\begin{array}{l}\text { Measuring cylinders } \\
\text { Microscopes } \\
\text { Bunsen burners }\end{array}$ \\
\hline $\begin{array}{l}\text { Middle of the } \\
\text { year } \\
\text { (January- } \\
\text { February } \\
\text { 2015) }\end{array}$ & $\begin{array}{c}\text { Literature compar- } \\
\text { ison and recount } \\
\text { Word card strategy } \\
\text { Extensive reading } \\
\text { and literature dis- } \\
\text { cussion }\end{array}$ & $\begin{array}{c}\text { Decimals, fractions } \\
\text { and percentages }\end{array}$ & $\begin{array}{c}\text { Chromatography } \\
\text { Distillation } \\
\text { Concentration/Solvents } \\
\text { and solutions }\end{array}$ \\
\hline $\begin{array}{l}\text { End of the } \\
\text { year } \\
\text { (June-July } \\
\text { 2015) }\end{array}$ & $\begin{array}{l}\text { Vocabulary revi- } \\
\text { sion } \\
\text { Grammatical in- } \\
\text { struction } \\
\text { Literature discus- } \\
\text { sion } \\
\text { Intensive reading } \\
\text { Vocabulary in- } \\
\text { struction }\end{array}$ & $\begin{array}{l}\text { Measurement of } \\
\text { volume } \\
\text { Developing an indi- } \\
\text { vidual revision unit } \\
\text { to prepare for } \\
\text { Grade } 7 \text { mathemat- } \\
\text { ics }\end{array}$ & $\begin{array}{l}\text { Fossil fuel formation } \\
\text { Fuel lab }\end{array}$ \\
\hline
\end{tabular}

TABLE 2: Topics covered in each subject in the three collection phases

A quick look at these topics alone suggests that the vocabulary load of these subjects will be quite different. Here are samples of the teacher talk from all three subjects. These examples illustrate differences in content between the three classes (e.g. characters in a novel; Mathematic equations), provide some evidence of the use of teacher talk for classroom management mentioned earlier in Horst's (2010) study, and demonstrate the kinds of vocabulary in the corpus.

\section{EAL example}

Num / that's number four yeah. Characters look like. So, some of the stories are little bit thin on description of these characters and what they actually look like. But you are going to need to think about what they actually look like from the description. And again, some of the stories have pictures of characters in them. 


\section{Maths example}

Ok. So, if we work with this example one more time, ok. Are you guys with me?

Shhh. Yeah. We first asked ourselves, ok, how many times does 2 fit into 7 ? Three times. Which actually gives us, 2 times 3 gives us 6 . So 7 minus 6 , we still have 1 leftover. 2 fits into 7 three times, which is 6 , not 7 , so we have 1 leftover. We bring down the next digit.

How many times does 2 fit into 16 ?

8 times.

8 times. Which in fact gives us exactly 16 so there's no remainder. We used up all of our digits, there's nothing left here. So our final answer, or the quotient, is 38.

\section{Science example}

No, no, no. Ah, yes, it's even, this week's a B week, next week's A. Ahhhhh.

No it's A now, next week is B week. That means that

But in B week's we don't see each other on Mondays, right, so we have only two sessions. Hmm. Now I have to think about what we should do first, first the microscope, or first the Bunsen burner.

Bunsen burner!

Ok, that's it we do the Bunsen burner first then. Then we do the microscope next week. Good.

\section{[2.1] Data analysis}

The analysis was carried out using Heatley, Nation \& Coxhead's (2002) Range Programme and Nation's (2016) BNC/COCA 25,000. These frequency-based word lists were developed from the British National Corpus (BNC) and the Contemporary Corpus of American English (COCA) (Davies, 2008). The lists are accompanied by supplementary lists of proper nouns, marginal words which commonly occur in speech (e.g. mmmm and ah), abbreviations, and compound nouns. Words which did not appear in the BNC/COCA 25,000 from the teacher talk corpus were examined and categorised like this:

(i) Word family members of the BNC/COCA were added to those lists.

(ii) Words outside the BNC/COCA lists were made into a new list of just teacher talk words, including German words such as Geschmack. 


\section{[3] RESULTS}

Research Question One: What is the vocabulary load of teacher talk from EAL, Maths and Science?

Table 3 shows the same coverage at 95\% for EAL and Maths, at 2000 plus proper nouns and marginal words, while Science sits at 3000 . These figures fit with van Zeeland \& Schmitt's (2013) estimates of language learners needing between 2,000 to 3,000 word families to understand spoken English. Table 3 also shows the $98 \%$ coverage figures for comparison. The $98 \%$ figures represent listening without support, and the vocabulary loads are higher. In both the $95 \%$ and $98 \%$ scenario, Science requires more vocabulary than the other two subjects. This finding is no surprise, given the kinds of topics outlined in Table 2 from the Science class. The Maths class has higher coverage also at $98 \%$ than EAL, which can also be explained by the topics in Table 2 .

\begin{tabular}{cccc}
\hline Coverage & EAL & Maths & Science \\
\hline $\begin{array}{c}\text { 95\% with proper nouns and } \\
\text { marginal words }\end{array}$ & 2000 & 2000 & 3000 \\
$\begin{array}{c}\text { 98\% with proper nouns and } \\
\text { marginal words }\end{array}$ & 4000 & 6000 & 7000 \\
\hline
\end{tabular}

TABLE 3: Vocabulary load over EAL, Maths and Science teacher talk at 95\% and $98 \%$

Table 4 provides coverage figures and examples from high, mid and low frequency vocabulary (Schmitt \& Schmitt, 2012) and supplementary lists for the whole data set. The first 1,000 words cover $89.16 \%$ of what the teacher said and the first 3000 words account for just over $94 \%$. 


\begin{tabular}{|c|c|c|c|c|}
\hline & Word level & Coverage \% & $\begin{array}{l}\text { Cumulative } \\
\text { coverage } \%\end{array}$ & Examples \\
\hline \multirow{3}{*}{$\begin{array}{c}\text { High } \\
\text { frequency }\end{array}$} & 1st 1000 & 89.21 & 89.21 & actual; bit; class \\
\hline & 2nd 1000 & 3.99 & 93.2 & percent; lesson \\
\hline & 3rd 1000 & 1.54 & 94.74 & focus; task; summary \\
\hline $\begin{array}{c}\text { Mid } \\
\text { Frequency }\end{array}$ & $4^{\text {th }}-8$ th 1000 & 2.24 & 96.98 & $\begin{array}{l}\text { pencil; diary; vocabu- } \\
\text { lary; underline }\end{array}$ \\
\hline \multirow[t]{3}{*}{$\begin{array}{c}\text { Low } \\
\text { Frequency }\end{array}$} & $9^{\text {th }}-25,000$ & 0.79 & 97.77 & brainstorm; semester \\
\hline & Proper nouns & 0.39 & 98.16 & $\begin{array}{l}\text { Germany; English; Co- } \\
\text { ca-Cola }\end{array}$ \\
\hline & $\begin{array}{c}\text { Marginal } \\
\text { words }\end{array}$ & 1.48 & 99.64 & ah; oh; um; uhm \\
\hline \multirow[t]{3}{*}{$\begin{array}{l}\text { Supplemen- } \\
\text { tary lists }\end{array}$} & $\begin{array}{l}\text { Compound } \\
\text { words }\end{array}$ & 0.31 & 99.95 & $\begin{array}{l}\text { worksheet; homework; } \\
\text { notebook }\end{array}$ \\
\hline & Abbreviations & 0.03 & 99.98 & div; org \\
\hline & Local words & .02 & 100.00 & $\begin{array}{c}\text { capiche; geschmack; } \\
\text { tankstelle; McPaper; } \\
\text { classbook }\end{array}$ \\
\hline Total & & 100.00 & 100 & \\
\hline
\end{tabular}

TABLE 4: Teacher talk corpus vocabulary load with BNC/COCA and supplementary word lists

The next section focuses on the three subjects again, but this time looking at the vocabulary load figures over each of the three times recorded in the school year.

Research Question Two: Does the vocabulary load figures change over the course of a school year?

The vocabulary load of the whole corpus at $95 \%$ with proper nouns and marginal words changed from 2000 to 3000 from Time 1 to Time 2, and stayed at 3,000 for Time 3. That said, Table 5 shows that the vocabulary load of the EAL and Maths classes stays constant from Time 2 to Time 3, but Science increases from 3000 to 4000 and back to 3000 . That is, Science stays consistently higher than the other two subjects. Therefore, Science is having an impact on the vocabulary load of the whole corpus. 


\begin{tabular}{cccc}
\hline $\begin{array}{c}\text { 95\% coverage with } \\
\text { proper nouns and } \\
\text { marginal words }\end{array}$ & EAL & Maths & Science \\
\hline Time 1 & 2,000 & 2,000 & 3,000 \\
Time 2 & 2,000 & 2,000 & 4,000 \\
Time 3 & 2,000 & 2,000 & 3,000 \\
\hline
\end{tabular}

TABLE 5: Vocabulary load coverage over three times of recording for EAL, Maths and Science

These figures in each of the subjects and times of recording are affected by differences in percentages of proper nouns and marginal words. EAL uses the most proper nouns on average $(0.77 \%)$, followed by Maths $(0.75 \%)$ and then Science $(0.37 \%)$, but Science has more marginal words on average $(1.82 \%)$ than EAL (1.28\%) and Maths (0.20\%).

Research Question Three: What coverage do the AWL and EAP Science word lists have over the teacher talk over the whole corpus and individually in Science, Maths and EAL?

Coxhead's (AWL) covers 1.92\% of the teacher talk corpus overall. A comparison of the coverage over the three subjects at each time (Table 6) shows that the AWL increases over time in all classes. The average coverage of this list is highest for the EAL class, followed by Maths and then Science. These figures are roughly half the coverage of the AWL over spoken academic texts at university level (Dang \& Webb, 2014).

\begin{tabular}{ccccc}
\hline AWL & Time 1 & Time 2 & Time 3 & Average \\
\hline EAL & 0.95 & 2.02 & 2.54 & 1.8 \\
Maths & 1.04 & 1.52 & 2.78 & 1.78 \\
Science & 1.1 & 1.63 & 2.05 & 1.59 \\
\hline
\end{tabular}

TABLE 6: Coverage of the AWL over EAL, Maths and Science teacher talk at Time 1 , Time 2 and Time $3(\%)$

The Science teacher talk has the highest coverage of the EAP Science List, as Table 7 shows, and this finding is not surprising. The highest coverage is $1.8 \%$ in Time 2 in Science. 


\begin{tabular}{ccccc}
\hline $\begin{array}{c}\text { EAP science } \\
\text { list }\end{array}$ & Time 1 & Time 2 & Time 3 & Three Times \\
\hline EAL & 0.08 & 0.12 & 0.06 & 0.08 \\
Maths & 0.64 & 0.85 & 0.6 & 0.72 \\
Science & 0.91 & 1.8 & 1.14 & 1.31 \\
\hline
\end{tabular}

TABLE 7: Coverage of the EAP Science list over the EAL, Maths, and Science teacher talk corpus Time 1, Time 2 and Time 3 (\%)

A quick analysis of Greene \& Coxhead's (2015) Middle School Vocabulary Lists found the Mathematics list covered 3.39\% of the Maths teacher talk (higher than the AWL over the Maths corpus), suggesting that this list has some potential for highlighting subject-specific vocabulary in context. The Science Middle School List covered $2.39 \%$ of the Science teacher talk, which is higher than the $1.31 \%$ of the EAP Science List and the $1.61 \%$ of the AWL. The English Grammar and Writing Middle School List covered $1.87 \%$ of the EAL, just under the AWL coverage. Clearly these lists require some further investigation.

\section{[4] DISCUSSION：OPPORTUNITIES AND CHALLENGES}

The coverage figures from the BNC/COCA, AWL and EAP Science word list suggest that at the beginning of the school year, regardless of the subject, these three teachers used more high-frequency words than academic words and specialized words. As the year progresses, they use fewer high-frequency words and more academic words. It appears that this vocabulary changes as the classes progress through the year and students' vocabulary knowledge and knowledge of the disciplines increase. High frequency vocabulary makes up a large proportion of this teacher talk data, just as it does in everyday English and in a wide variety of written texts (Nation, 2013). Learners with a low Vocabulary Levels Test score will encounter high frequency words in English in their EAL, Maths and Science classes, as Gierlinger \& Wagner (2016) found in Chemistry, Geography and History. Assessing vocabulary knowledge at the start of studies and monitoring its development is an important task for teachers (Nation, 2013). At this school, students were offered language support in the form of additional English classes based on low vocabulary scores. This study bears out how wise that decision is, given the prevalence of high frequency vocabulary in the EAL class.

This data also shows that the secondary school teacher talk in this corpus, like secondary school textbooks, appears to contain fewer AWL words than university level spoken texts (Dang \& Webb, 2014; Watanabe, 2013) and written texts (Coxhead, 2000). Perhaps, as Gibbons (2006) suggests, teacher talk serves 
as a bridge between everyday discourse and the academic register of school and the later vocabulary of higher studies. Teacher talk seems to offer opportunities for encountering the highly important high frequency vocabulary, across subjects, with a stretch of a higher vocabulary load in the Sciences. Coxhead (2000) found that the Sciences contained lower proportions of high frequency and higher proportions of AWL vocabulary in her academic written corpus, which suggests that this higher vocabulary load continues into university level study.

This study reinforces the importance of high frequency words and therefore the opportunity and need to create a high frequency list in a given context. Lexical items such as pencil, diary, vocabulary and underline are in the midfrequency word lists of the BNC/COCA lists, but they would be very high frequency items in school. These are vital for school contexts when we think about what EAL beginners need to be quickly taught.

At the research site, subjects such as Science and Maths are not 'streamed' for language level, which means one of the teaching dilemmas is how to speak to both weak language learners, and native speakers of the language in the one class. This study highlights the importance of teacher-modified materials to supplement their oral discourse by reinforcing basic vocabulary meanings and, importantly, the need for EAL classes to incorporate the high frequency, essential vocabulary from other subject areas as part of the EAL cross-curricular language support.

Another challenge highlighted in this study is that students who come into class part-way through a school year face higher vocabulary loads than students who start school at the beginning of the year. And finally, while those who need the first 1000 words of English will find these words in their classes, they are likely to struggle with the content of the teacher talk in class until they have acquired this high frequency lexis.

\section{[5] Limitations}

The corpus size for each of the subject areas is relatively small, which limits the generalisabilty of these results. Also, the word lists used here are based on written texts. Spoken word lists would be useful for future analysis. There are also no corroborating data on comprehension of teacher talk by the learners in the classes, or observations or interviews to find out more about listening comprehension. It is clear that the talk of these three teachers has different vocabulary profiles, so a further study could perhaps tease apart these differences more. More academic word lists which could be used for this analysis, including Gardner \& Davies' Academic Vocabulary List (AVL) (2014). This list was not used 
because the earlier studies in this article are based on the AWL, so comparability with written texts is limited. That said, the AVL, like the AWL, was based on university level texts.

\section{[6] FURTHER RESEARCH AND CONCLUSION}

Horst's (2010) analysis of teacher talk suggested a high proportion of the teacher talk involved class management. The data from the present study could also be examined and categorised. It would be useful to find out whether the same proportions are reported in secondary school data, and therefore what functions and language are needed by learners with low proficiency in the beginning of their secondary school studies. A larger-scale replication study might shed more light on the lexis used by teachers in class in the same subjects and others, at different years of schooling, and in English-medium contexts as well as first language contexts.

As Nation (2016) points out, academic vocabulary cuts across high-, mid-, and low-frequency words; so academic words can be both academic and high frequency or academic and mid frequency. This point needs much more investigation in secondary school spoken English. More analysis of this teacher talk data needs to be done to examine how the teachers approach vocabulary and focus on it (or not) in their classroom.

Finally, this research focused only on single words, but a multi-word unit analysis would also be useful. Biber's (2006) study on lexical bundles in classroom talk at university level would be a good starting point for such an analysis, as well as the spoken data of Academic Formulas from Simpson-Vlach \& Ellis (2010), but bearing in mind that these studies are based on university contexts. Secondary school spoken and written texts clearly are in need of much more research from a vocabulary perspective.

\section{AC KNOWLEDGEMENTS}

I would very much like to thank the three teachers who took part in this study, and the research assistants: Yen Dang, Friederike Tegge, Debbie Evans and Jeremy Koay. This research was funded by the Faculty of Humanities and Social Sciences at Victoria University of Wellington/ Te Whare Wānanga o te Ūpoko o te Ika a Māui, Aotearoa/New Zealand. 


\section{REFERENCES}

Biber, Douglas. 2006. University language. John Benjamins.

Coxhead, Averil. 2000. A new academic word list. TESOL Quarterly, 34(2), 213238.

Coxhead, Averil. 2011. The Academic Word List ten years on: Research and teaching implications. TESOL Quarterly, 45(2), 355-362.

Coxhead, Averil \& David Hirsh. 2007. A pilot science word list for EAP. Revue Française de Linguistique Appliqueé XII(2), 65-78.

Coxhead, Averil, Liesje Stevens \& Jenna Tinkle. 2010. Why might secondary science textbooks be difficult to read? New Zealand Studies in Applied Linguistics, $162,35-52$.

Dang, Yen \& Stuart Webb. 2014. The lexical profile of academic spoken English. English for Specific Purposes, 33, 66-76.

Davies, Mark. 2008. The Corpus of Contemporary American English: 520 million words, 1990-present. Available online at http://corpus.byu.edu/coca/.

Gardner, Dee \& Mark Davies. 2014. A new academic vocabulary list. Applied Linguistics, 35(3), 305-327.

Gierlinger Erwin \& Thomas Wagner. 2016. The more the merrier - revisiting CLIL-based vocabulary growth in secondary education. LACLIL, 9(1), 37-63.

Gibbons, Pauline. 2006. Bridging discourses in the ESL classroom: Students, teachers and researchers. London: Continuum.

Greene, Jennifer \& Averil Coxhead. 2015. Academic vocabulary for Middle School students: Research-based lists and strategies for key content areas. Brookes Publishing.

Heatley, Alex, Paul Nation \& Averil Coxhead. 2002. The Range Programme. Available at http://www.victoria.ac.nz/lals/about/staff/paul-nation.

Henriksen, Birgit \& Lise Danelund. 2015. Studies of Danish L2 learners' vocabulary knowledge and the lexical richness of their written production in English. In Päivi Pietilä, Katalin Doró, Renata Pípalová (Eds.), Lexical issues in L2 writing. Cambridge: Scholars Publishing, 1-27.

Horst, Marlise. 2010. How well does teacher talk support incidental vocabulary 
acquisition? Reading in a foreign language, 22(1), 161-180.

Nation, Paul. 1983. Testing and teaching vocabulary. Guidelines, 5(1), 12-25.

Nation, Paul. 2006. How large a vocabulary is needed for reading and listening? Canadian Modern Language Review, 631, 59-82.

Nation, Paul. 2013. Learning vocabulary in another language, second edition. Cambridge University Press.

Nation, Paul. 2016. Making and using word lists for language learning and testing. John Benjamins.

Nation, Paul \& Stuart Webb. 2011. Researching and analyzing vocabulary. Heinle \& Heinle.

Nurweni, Ari \& John Read. 1999. The English vocabulary knowledge of Indonesian university students. English for Specific Purposes, 18(2), 161-75.

Olmos, Carmen. 2009. An assessment of the vocabulary knowledge of students in the final year of secondary education. Is their vocabulary extensive enough? International Journal of English Studies, Special Issue, 79-90.

Schmitt, Norbert \& Diane Schmitt. 2012. A reassessment of frequency and vocabulary size in L2 vocabulary teaching. Language Teaching, 47(4), 484-503.

Simpson-Vlach, Rita \& Nick Ellis. 2010. An academic formulas list: New methods in phraseology research. Applied Linguistics, 31(4), 487-512.

Tang, Eunice. 2011. Non-native teacher talk as lexical input in the foreign language classroom. Journal of Language Teaching \& Research, 21, 45-54.

van Zeeland, Hannah \& Norbert Schmitt. 2013. Lexical Coverage in L1 and L2 Listenng Comprehension: The Same or Different from Reading Comprehension? Applied Linguistics, 344, 457-479.

Watanabe, Yoshinori. 2013. Profiling lexical features of teacher talk in CLIL courses: The case of a higher education EAP programme in Japan. International CLIL Research Journal, 21, 4-18.

Webb, Stuart \& Anna Chang. 2012. Second language vocabulary growth. RELC Journal, 43(1), 113-126.

West, Michael. 1953. A general service list of English words. London: Longman. 
CONTACTS

Averil Coxhead

Victoria University of Wellington

averil. coxhead@vuw.ac.nz 